\title{
Korelasi Faktor yang Berhubungan dengan Kejadian Pneumonia Balita di Dua Puskesmas Kota Jambi
}

\author{
Armina $^{1}$, Arnati Wulansari ${ }^{2}$ \\ ${ }^{1,2}$ Sekolah Tinggi Ilmu Kesehatan Baiturrahim, \\ J1. Prof. M. Yamin, SH. No. 30, Lebak Bandung, Jelutung, Kota Jambi, Jambi - 36135 \\ Correspondence email: arminanurwa86@gmail.com
}

\begin{abstract}
Abstrak. Prevalensi kasus pneumonia pada balita di Provinsi Jambi mengalami peningkatan beberapa tahun terakhir terutama kota Jambi pada tahun 2015 sebesar 44,14\%. Kasus pneumonia juga banyak tercatat di Puskesmas kota Jambi. Tujuan penelitian ini untuk mengidentifikasi faktor yang berkorelasi dengan kejadian pneumonia balita di dua puskesmas kota Jambi. Penelitian dilakukan di lokasi Wilayah Kerja Puskesmas Tahtul Yaman dan Kebon Handil dengan desain penelitian korelasi case control. Teknik sampling dengan purposive dengan jumlah sampling 55 (case) dan 55 (control). Uji analisis menggunakan Chi Square dan Regresi Logistik. Melalui Uji Chi Square didapatkan bahwa faktor riwayat ASI eksklusif, riwayat ISPA, pendidikan Ibu, riwayat pengobatan dan lingkungan ada hubungan yang signifikan dengan kejadian pneumonia balita (p value $<0,05$ ). Hasil uji model regresi logistik ditemukan bahwa faktor yang paling berkorelasi dengan kejadian pneumona yaitu riwayat ASI eksklusif, riwayat ISPA, dan riwayat pengobatan. Peneliti mengharapkan ada upaya untuk meningkatkan kesadaran ibu akan pencegahan pneumonia balita.
\end{abstract}

Kata kunci: anak balita; ASI eksklusif; pneumonia

\begin{abstract}
The prevalence of pneumonia in infants in Jambi province has increased the last few years, especially the city of Jambi in 2015 by 44.14\%. Pneumonia is also widely recorded in the health center of Jambi. The purpose of this research is to identify factors that correlate with the incidence of infant pneumonia in two centers of Jambi City. The research was conducted at the site of Tahtul Yaman and Kebon Handil Puskesmas working area with the design of case control correlation. Sampling technique with purposive sampling amount of 55 (case) and 55 (control). Test the analysis using Chi Square and logistic regression. The Chi Square test is derived that the exclusive ASI-history factor, ISPA history, Mother's education, treatment history and environment has a significant relationship with the incidence of infant pneumonia (P value $<0.05)$. The test results of a logistic regression model found that the most correlated factor of Pneumona is the exclusive ASI-history, ISPA history, and treatment history. Researchers expect an effort to raise the awareness of mothers on prevention of infant pneumonia.
\end{abstract}

Keywords: toddler; exclusive breast milk; pneumonia

\section{PENDAHULUAN}

Pneumonia menjadi salah satu penyakit infeksi saluran pernafasan akut bagian bawah sebagai penyumbang terhadap morbiditas dan mortalitas anak balita. Angka kejadian pneumonia di Indonesia berdasarkan laporan Riset Kesehatan Dasar (Kemenkes RI, 2013 dan 2015) pada bayi sebesar 1,8\% sedangkan pada balita sebesar 4,5\%. Berdasarkan laporan Riskesdas tersebut, ditemukan bahwa kasus pneumonia tertinggi pada usia $12-23$ bulan $(21,7 \%)$ dan pada usia bayi usia 0 11 bulan terjadi sekitar $13,6 \%$ mengalami pneumonia. Ini menunjukkan kasus pneumonia banyak ditemukan pada anak di bawah dua tahun. Jumlah kasus pneumonia di Indonesia ditemukan tertinggi di provinsi Nusa Tenggara Timur sebesar 4,6\% dari 1.027.766 responden. Sedangkan provinsi Jambi termasuk 6 provinsi terendah yang mengalami pneumonia yaitu sekitar 1\% (Kemenkes RI, 2012). Berdasarkan angka kejadian terendah tersebut masih menunjukkan angka yang cukup tinggi di Indonesia dengan melihat dampak lanjut yaitu kematian pada balita.

Prevalensi kasus pneumonia pada balita di Provinsi Jambi tahun 2012 sebesar 21,7\% atau 5.972 kasus dan tahun 2015 meningkat menjadi 21,19\% atau 6.873 kasus. Pada tahun 2015 tersebut, kasus pneumonia tertinggi berada di Kota Jambi dibanding kabupaten lain di provinsi Jambi yaitu sebesar 44,14\% (Dinkes Prov. Jambi, 2016). Selain itu, hasil survei di Ruang Anak RSUD Raden Mattaher Jambi terkait kasus bronkopneumonia selama bulan Januari hingga bulan Juni 2018 menunjukkan selalu terdapat pasien dengan penyakit tersebut yaitu 5 hingga 14 pasien per bulan. Berdasarkan data dari Dinas Kesehatan Kota Jambi tahun 2016 bahwa 20 Puskesmas di Kota Jambi terdapat 1.229 kasus pneumonia dan Puskesmas Tahtul Yaman menjadi lokasi kasus tertinggi pneumonia pada balita 1-5 tahun yaitu 188 kasus dan diikuti Puskesmas Kebun Handil sebanyak 185 kasus pneumonia (Dinkes Kota Jambi, 2016).

Pneumonia merupakan peradangan yang mengenai parenkim paru dengan terjadinya konsolidasi ruang alveolar (Hockenberry \& Wilson, 2015). Penyebab terjadinya pneumonia berasal dari bakteri, virus dan mikroorganisme seperti Streptococcus pneumoniae, Haemophilus influenza, Mycoplasma pneumonia dan sebagainya (Ball et al, 2010). Gejala 
penyakit ini berupa napas cepat dan napas sesak, karena paru meradang secara mendadak. Batas napas cepat adalah frekuensi pernapasan sebanyak 50 kali permenit atau lebih pada anak usia 2 bulan sampai kurang dari 1 tahun, dan 40 kali permenit atau lebih pada anak usia 1 tahun sampai kurang dari 5 tahun (Kemenkes RI, 2015).

Tingginya angka kejadian pneumonia tidak terlepas dari faktor risiko pneumonia. Menurut Kemenkes RI dalam buletin penumonia balita tahun 2010 (Kemenkes RI, 2010), faktor risiko yang pneumonia diantaranya nutrisi kurang (status gizi), kurangnya pemberian ASI eksklusif, imunisasi tidak adekuat, polusi termasuk polusi rokok, riwayat infeksi pernapasan saluran atas, berat lahir rendah, dan pendidikan ibu rendah. Saat ini belum diketahuinya faktor yang berkontribusi terhadap tejadinya pneumonia pada balita di Provinsi Jambi. Berdasarkan fenomena tersebut, peneliti tertarik melakukan penelitian yang berjudul "Korelasi Faktor yang berhubungan dengan Kejadian Pneumonia Balita di dua Puskesmas Kota Jambi". Tujuan umum penelitian ini adalah untuk mengetahui faktor risiko pneumonia pada anak balita di dua Puskesmas Kota Jambi.

\section{METODE}

Penelitian ini merupakan penelitian kuantitatif dengan desain korelasi dengan pendekatan penelitian
Case Control yang bertujuan untuk mengetahui hubungan antara variabel independen (riwayat imunisasi, riwayat ISPA, riwayat ASI eksklusif, pendidikan ibu, kebiasaan merokok keluarga di rumah, pengetahuan, riwayat pengobatan dan lingkungan) dengan variabel dependen (kejadian pneumonia) di dua Puskesmas Kota Jambi. Tempat penelitian di wilayah kerja Puskesmas Tahtul Yaman dan Kebon Handil.

Responden penelitian ini adalah ibu yang memiliki anak balita pneumonia dari data puskesmas dengan kelompok kasus sampel 55 responden dan kelompok kontrol 55 (balita tidak pneumonia). Teknik pengambilan sampel pada penelitian ini menggunakan metode purposive sampling. Instrumen yang digunakan adalah lembar kuesioner yang diisi oleh responden. Etika penelitian pada penelitian ini menganut prinsip autonomy / respect of human dignity, anonimity. Analisis data menggunakan analisis univariat, sedangkan analisis bivariat dengan uji Chi Square dan multivariat dengan model Regresi Linier ganda.

\section{HASIL DAN PEMBAHASAN}

Berdasarkan hasil penelitian ini secara umum bahwa di dua puskesmas tempat penelitian terlihat pada tabel 1 .

Tabel 1. Hubungan antara faktor usia balita, jenis kelamin, berat lahir balita, riwayat ASI eksklusif, riwayat imunisasi, riwayat ISPA, pendidikan riwayat pengobatan, kebiasaan merokok, pengetahuan ibu, dan lingkungan rumah dengan kejadian Pneumonia di dua Puskesmas Kota Jambi $(\mathrm{n}=110)$

\begin{tabular}{|c|c|c|c|c|c|c|c|}
\hline \multirow{3}{*}{ No } & \multicolumn{7}{|c|}{ Kelompok } \\
\hline & \multirow[t]{2}{*}{ Variabel/ Kategori } & \multicolumn{2}{|c|}{ Kasus } & \multicolumn{2}{|c|}{ Kontrol } & \multirow[t]{2}{*}{ P value } & \multirow{2}{*}{$\begin{array}{c}\text { OR } \\
\text { CI95\% }\end{array}$} \\
\hline & & $\mathbf{n}$ & $\%$ & $\mathbf{n}$ & $\%$ & & \\
\hline \multirow[t]{2}{*}{1} & Usia balita : 12-24 Bulan & 8 & 14,5 & 6 & 10,9 & 0,567 & 1,390 \\
\hline & $>24-59$ Bulan & 47 & 85,5 & 49 & 89,1 & & $0,448-4,310$ \\
\hline \multirow[t]{3}{*}{2} & Jenis Kelamin balita : & & & & & & \\
\hline & Laki-Laki & 34 & 61,8 & 31 & 56,4 & 0,561 & 1,253 \\
\hline & Perempuan & 21 & 38,2 & 24 & 43,6 & & $0,585-2,684$ \\
\hline \multirow[t]{3}{*}{3} & Berat Badan Lahir balita : & & & & & & \\
\hline & $\leq 2500 \mathrm{gr}$ & 0 & 0 & 2 & 3,6 & 0,495 & 2,038 \\
\hline & $>2500 \mathrm{gr}$ & 55 & 100 & 53 & 96,4 & & $1,682-2,469$ \\
\hline \multirow[t]{3}{*}{4} & Riwayat ASI Eksklusif & & & & & & \\
\hline & Tidak Diberi ASI Eksklusif & 31 & 56,4 & 3 & 5,5 & 0,0001 & 22,389 \\
\hline & Diberi ASI & 24 & 43,6 & 52 & 94,5 & & $6,225-80,523$ \\
\hline \multirow[t]{3}{*}{5} & Riwayat Imunisasi & & & & & & $\mathrm{RR}$ \\
\hline & Imunisasi Tdk lengkap & 1 & 1,8 & 0 & 0 & 1,000 & 2,019 \\
\hline & Imunisasi Lengkap & 54 & 98,2 & 55 & 100 & & $1,670-2,440$ \\
\hline \multirow[t]{3}{*}{6} & Riwayat ISPA & & & & & & \\
\hline & Tidak & 51 & 92,7 & 28 & 50,9 & 0,0001 & 12,295 \\
\hline & $\mathrm{Ya}$ & 4 & 7,3 & 27 & 49,1 & & $3,905-38,705$ \\
\hline \multirow[t]{3}{*}{7} & Pendidikan Ibu & & & & & & $\mathrm{RR}$ \\
\hline & Cukup (SD, SMP, SMA) & 46 & 83,6 & 55 & 100 & 0,003 & 0,445 \\
\hline & Tinggi (Akademi, Perguruan Tinggi) & 9 & 16,4 & 0 & 0 & & $0,368-0,564$ \\
\hline \multirow[t]{3}{*}{8} & Kebiasaan Merokok dlm rumah & & & & & & \\
\hline & Tidak & 49 & 89,1 & 46 & 83,6 & 0,405 & 1,598 \\
\hline & Ada & 6 & 10,9 & 9 & 16,4 & & $0,527-4,842$ \\
\hline \multirow[t]{2}{*}{9} & Pengetahuan & & & & & & \\
\hline & Kurang Baik & 16 & 29,1 & 12 & 21,8 & 0,381 & 1,470 \\
\hline
\end{tabular}


Armina \& Arnati Wulansari, Korelasi Faktor yang Berhubungan dengan Kejadian Pneumonia Balita di Dua Puskesmas Kota Jambi

\begin{tabular}{|c|c|c|c|c|c|c|c|}
\hline & Baik & 39 & 70,9 & 43 & 78,2 & & $0,619-3,491$ \\
\hline \multirow[t]{3}{*}{10} & Pengobatan & & & & & & \\
\hline & Kurang Baik & 4 & 7,3 & 19 & 34,5 & 0,0001 & 0,149 \\
\hline & Baik & 51 & 92,7 & 36 & 65,5 & & $0,047-0,474$ \\
\hline \multirow[t]{3}{*}{11} & Lingkungan & & & & & & \\
\hline & Kurang Baik & 17 & 30,9 & 8 & 14,5 & 0,041 & 2,628 \\
\hline & Baik & 38 & 69,1 & 47 & 85,5 & & $1,024-6,748$ \\
\hline
\end{tabular}

Berdasarkan tabel 1 dapat diketahui hasil analisis bivariat dilakukan dengan uji Chi Square dan Fisher (data kategorik) dan juga menilai Odds Rasio bahwa riwayat ASI eksklusif, riwayat ISPA, Pendidikan Ibu, Riwayat pengobatan dan kondisi lingkungan memiliki hubungan yang signifikan dengan kejadian di dua puskesmas di Kota Jambi (Puskesmas Tahtul Yaman dan Kebon Handil) dengan nilai $\mathrm{p}<0,05$.

Hasil penelitian ini serupa dengan hasil penelitian Mardani (Mardani et al, 2018) yaitu riwayat ASI eksklusif ada hubungan yang signifikan dengan kejadian pneumonia balita di RSUD Kampar dengan $\mathrm{p}$ value 0,014. Namun hasil penelitian ini berbeda dengan Efni (Efni et al, 2018) bahwa ASI eksklusif tidak ada kejadian pneumonia balita di Keluarahan Air Tawar Padang ( $\mathrm{p}$ value 0,735). Hasil ini yang berbeda tersebut menunjukkan bahwa setiap daerah tersebut ibu balita memiliki riwayat ASI eksklusif dan dan ada yang tidak ASI eksklusif. Namun pada penelitian ini terlihat ibu balita memiliki riwayat ASI eksklusif lebih sedikit. Sehingga tidak adanya ASI eksklusif pada balita berdampak pada balita yang beresiko mengalami pneumonia. Terlihat pada nilai OR yakni 22,389 kali balita tidak ASI eksklusif mengalami pneumonia.

Sebagaimana diketahui bahwa Kemenkes menganjurkan agar bayi selama enam bulan pertama untuk diberikan ASI eksklusif karena sangat berperan dalam membantu bayi meningkatkan daya tahan tubuh terhadap serangan infeksi. ASI sendiri mengandung berbagai komponen seperti imunoglobulin A (Ig A) sekretori yang spesifik terhadap infeksi Clamydia. Kuman Clamydia sendiri dapat menyebabkan infeksi pada mata dan infeksi pada paru atau pneumonitis (Tumbelaka \& Karyanti, 2013). Oleh karena itu, ibu-ibu yang memiliki bayi agar diberikan ASI eksklusif tanpa pemberian makanan tambahan apapun agar kandungan ASI terserap secara maksimal oleh pencernaan bayi sehingga bayi menjadi lebih terlindungi dari kuman patogen yang berisiko termasuk kuman penyebab pneumonia.

Berdasarkan hasil penelitian ini juga terlihat bahwa balita yang memiliki riwayat ISPA yaitu dengan gejala batuk pilek sedikit, walaupun demikian nilai Odds Rasio menunjukkan angka 12,295 kali balita ISPA untuk mengalami penumonia. Hal ini menunjukkan bahwa ISPA telah berdampak pada mudahnya kuman lain yang masuk ke dalam saluran pernapasan disamping sang balita masih memiliki daya tahan tubuh rendah. Oleh karena itu, diharapkan ibu agar menghindarkan balita dari paparan kuman yang ditularkan melalui udara atau menghindarkan balia dari orang-orang yang terinfeksi ISPA.

Pada penelitian ini faktor pendidikan ibu juga memiliki peran dalam kejadian pneumonia ( $p$ value 0,003 ). Hal ini terlihat pada walaupun pendidikan ibu dengan kategori cukup namun ibu kemungkinan sering diberi edukasi pentingnya kesehatan bayi dan balita agar terhindar dari infeksi. Pihak Puskesmas tentunya telah banyak memberikan program edukasi kepada ibu dan balita. Hal kemungkinan lain menurut peneliti yaitu bahwa walaupun seorang ibu memiiliki pendidikan cukup namun naluri keibuan untuk melindungi bayi atau balita dari ancaman kesehatan akan terjadi secara alamiah sehingga menumbuhkan sikap dan perilaku yang positif demi melindungi sang balita. Oleh karena itu, pihak ibu yang memiliki bayi atau balita walaupun memiliki pendidikan cukup untuk sering mencari tahu mengenai kesehatan anak balita kepada tenaga kesehatan terdekat seperti di posyandu atau puskesmas pembantu.

Berdasarkan penilitian ini pada tabel 1 terlihat juga bawah riwayat pengobatan dan lingkungan juga memiliki hubungan yang bermakna dalam kejadian pneumonia. Hasil ini sedikit berbeda yaitu bahwa riwayat pengobatan terhadap ISPA dan lingkungan berkategori baik di dua puskesmas ini namun balita tetap mengalami kejadian Penumonia. Menurut peneliti, hal ini dikarenakan pneumonia mudah tertular dari pencemaran udara seperti rokok atau asap kendaraan karena kandungan tersebut lebih berat terhadap saluran pernapasan. Sedangkan riwayat pengobatan yang baik telah dilakukan namun dikarenakan balita memiliki daya tahan rendah sehingga pengobatan menjadi tidak optimal untuk mencegah anak balita dari terjadinya pneumonia. Walaupun secara statistik riwayat pengobatan ISPA dan lingkungan berkategori baik namun masih dapat berkontribusi terhadap terjadinya pneumonia hal ini ditunjukkan nilai OR pada lingkungan lebih tinggi 2,628 kali terhadap kejadian pneumonia. Oleh karena itu, ibu yang memiliki bayi atau balita agar menghindarkan bayi mereka dari polusi udara seperti asap rokok atau asap kendaraan.

Hasil penelitian ini berbeda dengan penelitian yang dilakukan oleh Rasyid (2013) yang menunjukkan berat badan lahir ada hubungan signifikan dengan kejdian pneumonia balita di RSUD kampar ( $p$ value 0,021). Hasil ini menurut peneliti karena balita ditemukan lebih sedikit berat lahir kurang dari 2500 gram yang berbeda kejadiannya di RSUD Kampar. 
Berdasarkan hasil penelitian ini pada tabel 1, bahwa faktor imunisasi dan kebiasaan keluarga merokok tidak memiliki hubungan signifikan dengan kejadian pneumonia di dua puskesmas ini. penelitian ini serupa dengan penelitian Mardani (Mardani et al, 2018). Hasil penelitian ini menunjukkan bahwa riwayat imunisasi lengkap diberikan dan kebiasaan merokok di dalam rumah jarang dilakukan sehingga secara statistik tidak berkontibusi dengan kejadian pneumonia. Hal ini menunjukkan bahwa aanak balita di dua puskesmas tersebut telah dibantu dalam perlindungan kekebalan pasif dengan adanya pemberian vaksin imunisasi yang lengkap terutama vaksin BCG, DPT dan vaksin campak. Selain itu kebiasaan merokok tidak di dalam rumah juga menghindarkan anak balita yang sering berada di dalam rumah terhindar dari timbulnya pneumonia. Peneliti menganjurkan agar anggota keluarga ketika merokok tidak berada dekat dengan anak balita demi menghidarkan anak balita dari paparan yang mengganggu kesehatan dikarenakan daya tahan tubuh anak balita yang masih rendah.

Tabel 2. Model regresi logistik Ganda faktor risiko yang berhubungan dengan kejadian pneumonia $(\mathrm{n}=110)$

\begin{tabular}{llcc}
\hline No & \multicolumn{1}{c}{ Variabel/ Kategori } & B & Sig. \\
\hline 1 & Riwayat ASI Eksklusif & $\mathbf{- 3 , 2 9 4}$ & $\mathbf{0 , 0 0 0}$ \\
2 & Riwayat ISPA & $\mathbf{- 1 , 8 0 5}$ & $\mathbf{0 , 0 0 6}$ \\
3 & Pengobatan & $\mathbf{2 , 8 7 0}$ & $\mathbf{0 , 0 0 1}$ \\
& Konstanta & $\mathbf{1 , 8 8 4}$ & $\mathbf{0 , 0 0 1}$ \\
\hline
\end{tabular}

Penelitian ini mencoba menganalisis hasil data hingga multivariat dengan regresi logistik ganda untuk menguji faktor-faktor mana yang berisiko terhadap kejadian pneumonia. Uji analisis multivariat diperoleh dengan melihat nilai signifikan (sig) pada uji bivariat sebelumnya yaitu nilai sig. $<0,25$. Variabel yang masuk dalam pemodelan regresi logistik adalah riwayat ASI eksklusif, riwayat ISPA, pendidikan Ibu, riwayat pengobatan dan kondisi lingkungan sesuai nial sig < 0,25 dan juga memasukkan variabel kebiasaan merokok karena dianggap berkaitan erat dengan pneumonia. Variabel tersebut dilakukan dengan sistem Backward dan menghasilkan pemodelan dengan nilai siginifikan < 0,05 yang menunjukkan bahwa fakor yang berkontribusi dalam kejadian pneumonia di dua puskesmas penelitian ini yaitu riwayat ASI eksklusif, riwayat ISPA, dan riwayat pengobatan.

Hasil penelitian ini membuktikan bahwa secara teori anak balita yang tidak diberi ASI eksklusif besar kemungkinan berpotensi menderita pneumonia dibanding dengan yang tidak diberikan ASI eksklusif. Kandungan ASI berupa IgA sekretori dan nutrisi lengkap sangat diperlukan untuk bayi yang berada dalam masa penyesuaian dengan lingkungan di luar rahim ibu. Pemberian ASI tanpa tambahan makanan lain selama enam bulan pertama kehidupan bayi dapat memberikan kekebalan terhadap berbagai macam penyakit terutama pneumonia karena ASI mengandung zat kekebalan tubuh yang dapat melindungi dirinya dari berbagai penyakit infeksi, bakteri, virus, jamur maupun parasit ${ }^{11}$. Sedangkan bayi yang terlalu cepat terpapar dengan makanan selain ASI seperti pisang atau air putih, bayi akan lebih berisiko cepat terpapar dengan infeksi karena berkaitan dengan kebersihan wadah makanan, sendok ataupun kebersihan makanan. Selain itu itu juga, pemberian makanan yang terlalu cepat pada bayi akan mengurangi asupan kekebalan dari ASI eksklusif (IgA) dan mengurangi nutrisi ASI yang masuk ke dalam tubuh bayi. Pencernaan bayi yang masih membutuhkan adaptasi dengan nutrisi yang sesuai dan proteksi dari ASI harus dihadapkan dengan paparan makanan lain yang memiliki tekstur berat untuk dicerna oleh pencernaan bayi. oleh karena itu, ASI eksklusif sangat dianjurkan diberikan pada bayi selama enam bulan pertama kehidupan agar bayi benar-benar mendapat kandungan ASI yang lebih optimal.

Riwayat ISPA dan riwayat pengobatan ISPA juga paling berkontribusi dengan kejadian pneumonia di dua puskesmas ini. diharapkan agar anak balita diupayakan dihindarkan dari apapran kuman atau virus penyebab ISPA dan pengobatan terhadap ISPA lebih ditingkatkan lagi untuk mengoptimalkan pengobatan. Pengobatan ISPA tidak hanya sekedar berupa pemberian obat namun pengobatan juga termasuk dalam perawatan selama anak balita mengalami ISPA dan terhindar dari memperparah ISPA anak balita.

Untuk itu diharapkan pihak puskesmas lebih aktif melakukan promosi kesehatan ke rumah warga berupa edukasi upaya pencegahan pneumonia terutama mengajarkan pentingnya pemberian ASI eksklusif dengan cara yang benar, edukasi penanganan penyakit ISPA serta edukasi pencegahan penyakit penumonia.

\section{SIMPULAN}

Berdasarkan hasil penelitian ini bahwa faktor yang paling berperan dalam berhubungan dengan kejadian pneumonia balita di dua puskesmas ini adalah riwayat ASI eksklusif ( $\mathrm{p}$ value $=0,0001$ ), riwayat ISPA ( $\mathrm{p}$ value $=0,006)$, dan riwayat pengobatan ( $\mathrm{p}$ value $=0,001)$.

\section{Saran}

Pihak puskesmas lebih aktif melakukan promosi kesehatan ke rumah warga berupa pendidikan kesehatan tentang upaya pencegahan pneumonia terutama mengajarkan pentingnya pemberian ASI eksklusif dengan cara yang benar, pemantauan kepatuhan ibu memberikan terapi perawatan ISPA sesuai anjuran tenaga kesehatan dan MTBS serta pendidikan kesehatan tentang pencegahan pneumoia. Saran penelitian berikutnya dapat dilakukan penelitian dengan desain kohort atau menilai kepatuhan ibu balita dalam melakukan terapi MTBS pada anak balita yang 
mengalami ISPA agar terhindar dari tingkat keparahan dan mencegah dari munculnya pneumonia.

\section{Ucapan Terima Kasih}

Peneliti mengucapkan terima kasih kepada Ristekdikti yang telah mendanai penelitian ini hingga selesai.

\section{DAFTAR PUSTAKA}

Ball, J.W., Bindler, R.C., \& Cowen, K.J. (2010). Child health nursing, partnering with children \& families. 2nd ed. New Jersey: Pearson Education Inc.

Bowden, V.R., \& Greenberg, C.S. (2010). Children and their families: The continuum of care. 2nd edition. Philadelphia: Lippincott Williams \& Wilkin.

Dinas Kesehatan Provinsi Jambi. (2016). Profil Kesehatan Provinsi Jambi 2015. Dinas Kesehatan Pemerintahan Provinsi Jambi

Dinas Kesehatan Kota Jambi. (2016). Laporan kasus pneumonia tahun 2016.

Efni, Y., Machmud, R., dan Pertiwi, D. (2016). Faktor Risiko yang Berhubungan dengan Kejadian Pneumonia pada Balita di Kelurahan Air Tawar Barat Padang. Jurnal Kesehatan Andalas, 5 (2), 365-370.

Hockenberry, M., \& Wilson, D. (2015). Wong's nursing care of infants and children. 10th Edition. St. Missouri: Mosby Elsevier

Kementerian Kesehatan Republik Indonesia. (2012). Profil kesehatan Indonesia 2012. Pusat Data dan Informasi. Jakarta : Kementerian Kesehatan RI. Diakses dari http://www.depkes.go.id/resources/download/pusd atin/profil-kesehatan-indonesia/profil-kesehatanindonesia-2012.pdf

Kementerian Kesehatan RI. (2010). Pneumonia balita. Pusat Data dan Surveilans Informasi. Buletin Jendela Epidemiologi, volume 3. Diakses dari www.depkes.go.id/download.php?file=download/ pusdatin/buletin/...pneumonia.pdf

Kementerian Kesehatan Republik Indonesia. (2015). Buku Bagan: Manajemen terpadu balita sakit (MTBS). Jakarta: Kementerian Kesehatan Republik Indonesia

Kementerian Kesehatan RI. (2013). Riset kesehatan dasar 2013. Kemenkes RI

Mardani, R.A., Pradigdo, S.F., \& Mawarni, A. (2018). Faktor risiko kejadian pneumonia pada anak usia 12-48 bulan (Studi di Wilayah kerja Puskesmas Gombong II Kabupaten Tahun 2017). Jurnal Kesehatan Masyarakat, 6 (1), 581-590.

Pusat Data dan Informasi Kemenkes RI. (2015). Situasi kesehatan anak balita di Indonesia. Diakses di http://www.depkes.go.id/resources/download/pusd atin/infodatin/infodatin-anak-balita.pdf
Rasyid, Z. (2013). Factors Associated With Occurenceof Childhood Pneumonia In Bangkinang Hospital Kampar Regency. Jurnal Kesehatan Komunitas, 2 (3), 136-140.

Tumbelaka, A.R, dan Karyanti, M.R. (2013). Air susu ibu dan pengendalian infeksi. Diakses dari http://www.idai.or.id/artikel/klinik/asi/air-susuibu-dan-pengendalian-infeksi 